Al-Mashlahah: Jurnal Hukum Islam dan Pranata Sosial Islam, VOL : 07, NO : 2, Oktober 2019

DOI : 10.30868/am.v7i2.592

ISSN : 2339-2800 (Media Cetak)

ISSN : 2581-2556 (Media Online)

\author{
DEVELOPMENT OF ISLAMIC ECONOMIC \\ CURRICULUM BASED ON TAUHID: Curriculum Study \\ Program of Islamic Economics Study Program STEI Tazkia Bogor
}

\title{
PENGEMBANGAN KURIKULUM EKONOMI ISLAM BERBASIS TAUHID: Studi Kurikulum Program Studi Ekonomi Islam STEI Tazkia Bogor
}

\author{
Arijulmanan $^{1}$ \\ ${ }^{1}$ Program Studi Ahwal Al-Syakhshiyah STAI Al Hidayah Bogor \\ email: arijul.manan@yahoo.co.id
}

\begin{abstract}
Every Moslem will business at Islamic Finance Institution must study and understand about fiqh mu'amalah. Understanding of fiqh muamalah must be studied about Islamic economic which its curriculum can studied at university. Moslem must study too about Tauhid, so need too Islamic Economic Curriculum Development on Tauhid base at university in Indonesia to Human Resource preparation for next Islamic Finance Institution. The study was focused on developing Islamic Economic Curriculum on Tauhid base at Tazkia Bogor. Curriculum development was focused on planning of curriculum at Islamic Economic Education, it's process, and curriculum evaluation from Islamic Economic on Tauhid based. The method of research is thematic with document based. The procedure of collection data is documentation from information waith observation at Islamic Economic Department of STEI Tazkia and library resources. Based on the results of observation about developing Islamic Economic Curriculum on Tauhid based at Islamic Economic Department, there are the aims of planning: a) to be student with sharia based, knowledge philosophy and developing method of Islamic Economic Department. b) to be national curriculum reference on developing Islamic Economic Department. c) have competence and indicator quantitative and qualitative of graduation from Islamic Economic Department on Islamic business Instutution and real sector and financial sector. d) benefit partnership institutional with another universities and industries in Indonesia and abroad. Islamic Economic curriculum application at Islamic Economic Department of STEI Tazkia did step by step and continuous improvement based on institution vision and mission. Curriculum evaluation did every 4 years with develop Islamic Economic curriculum as well as procedures.
\end{abstract}

Key word: curriculum, economic, tauhid.

\section{ABSTRAK}

Setiap Muslim yang akan berbisnis di lembaga keuangan syariah terlebih dahulu harus mempelajari dan memahami fikih mu'amalah. Pemahaman terhadap fikih muamalah bisa dilakukan dengan belajar memahami ekonomi Islam yang sudah ada kurikulumnya di perguruan tinggi. Agar tidak terlepas dari keyakinan seorang Muslim dengan Tauhid, maka perlu dilakukan pengembangan kurikulum ekonomi Islam berbasis Tauhid di perguruan tinggi yang ada di Indonesia dalam menyiapkan sumber daya manusia yang akan terjun dalam lembaga keuangan syariah kelak. Fokus masalah dalam penelitian ini 
adalah pengembangan kurikulum Ekonomi Islam berbasis Tauhid di Program Studi Ekonomi Islam Sekolah Tinggi Ekonomi Islam (STEI) Tazkia Bogor. Pengembangan kurikulum tersebut fokus pada perencanaan kurikulum pendidikan Ekonomi Islam, pelaksanaannya, dan evaluasi kurikulum pendidikan Ekonomi Islam berbasis Tauhid. Pendekatan yang digunakan dalam penelitian ini adalah pendekatan tematik berbasis dokumentatif. Sedangkan prosedur pengumpulan data yang peneliti gunakan adalah dokumentasi yaitu mengumpulkan data dan informasi melalui observasi ke lapangan di Program Studi Ekonomi Islam STEI Tazkia Bogor dan berbagai sumber kepustakaan. Hasil observasi tentang pengembangan kurikulum Ekonomi Islam berbasis Tauhid di STEI Tazkia menunjukkan bahwa perencanaan kurikulum pendidikan ekonomi Islam, bertujuan diantaranya: a) Membentuk mahasiswa berlandaskan syariah, filsafat ilmu, dan metode pengembangan Program Studi Ekonomi Islam; b) Menjadi referensi kurikulum nasional dalam pengembangan Program Studi Ekonomi Islam; c) Mempunyai kompetensi serta indikator kuantitatif maupun kualitatif lulusan Prodi Ekonomi Islam yang dapat memenuhi kebutuhan lembaga bisnis Islam baik di sektor riil maupun sektor keuangan; dan d) Terjalinnya kerjasama dan kemitraan institusional yang saling menguntungkan dengan lembaga pendidikan tinggi lain dan industri baik di dalam maupun di luar negeri. Pelaksanaan kurikulum Ekonomi Islam di Program Studi Ekonomi Islam STEI Tazkia Bogor dilakukan secara bertahap dan berkelanjutan dengan mengacu kepada visi dan misi lembaga. Evaluasinya dilakukan secara terus menerus berkelanjutan dengan memperhatikan kebutuhan industry, sedangkan pengenbangan terus dilakukan setelah evaluasi setiap 4 tahun sekali dengan memasukkan nilai-nilai Tauhid di setiap mata kuliah.

Kata Kunci: kurikulum, ekonomi, tauhid.

\section{A. PENDAHULUAN}

Membicarakan masalah pendidikan adalah membicarakan masalah peradaban umat manusia. Berdasarkan sejarah yang ada, terutama sejarah ummat Islam, perjalanan maju mundurnya peradaban ummat Islam dalam kurun waktu sekian abad itu dapat dibaca melalui dimensi pendidikannya. Proses membangun peradaban dan pendidikan merupakan dua ranah setali mata uang yang tidak pernah tuntas sepanjang kehidupan manusia itu masih eksis.
Secara filosofis, tujuan pendidikan adalah mengembangkan potensi manusia ke arah yang maksimal. Sebab, potensi yang diberikan oleh Allah S.W.T. tidak akan berkembang dengan sendirinya tanpa sentuhan pendidikan yang memadai. Sentuhan pendidikan itu mencakup wilayah jasmaniyah maupun ruhaniyah, seperti spiritual, nilai-nilai etis (akhlak) atau budi pekerti.

Perguruan tinggi memiliki peran yang sangat strategis dalam rangka pembangunan nasional, terutama dalam upaya pengembangan sumber daya manusia pada masa yang akan datang. 
Kualitas sumber daya manusia itu tentunya dicapai berkat adanya peningkatan kualitas lulusan perguruan tinggi itu sendiri.

Untuk meningkatkan kualitas lulusan perguruan tinggi, diperlukan peningkatan sistem pendidikan, yang intinya terletak pada kurikulum yang dikembangkan dan dilaksanakan pada lembaga pendidikan tinggi tersebut. Kurikulum dapat dianggap sebagai suatu alat yang penting dalam upaya mencapai tujuan pendidikan tinggi, sedangkan ketercapaian tujuan tersebut merupakan bagian yang integral dalam upaya pencapaian tujuan pendidikan nasional. $^{1}$

Kurikulum merupakan alat yang sangat penting bagi keberhasilan suatu pendidikan. Tanpa kurikulum yang sesuai dan tepat akan sulit untuk mencapai tujuan dan sasaran pendidikan yang diinginkan.

\section{Mengembangkan}

kurikulum bukanlah pekerjaan yang mudah dan sederhana karena banyak sekali pertanyaan yang dapat dikemukakan untuk dipertimbangkan. Misalnya: Apakah yang ingin dicapai? Manusia

${ }^{1}$ Oemar Hamalik. (1994). Pengembangan Kurikulum dan Pembelajaran di Perguruan Tinggi. Bandung: PT Trigenda Karya. yang bagaimana yang diharapkan akan dibentuk? Apakah yang diutamakan kebutuhan sekarang atau masa mendatang? Apakah hakikat peserta didik harus dipertimbangkan atau diperlukan sebagai orang dewasa?

Melalui kurikulum yang sesuai dan tepat, maka dapat diharapkan sasaran dan tujuan pendidikan akan dapat tercapai secara maksimal.

Tujuan pendidikan dalam Islam adalah untuk memperkuat aqidah tauhid dan keimanan kepada Allah S.W.T., mengasah dan meningkatkan kecerdasan, mempelajari ilmu pengetahuan dan teknologi, memanfaatkan dan mempergunakan alam semesta berdasarkan aturan-Nya. Belajar dilandasi dengan nama Allah agar niatnya baik dan benar serta jelas manfaatnya, menumbuhkembangkan kesadaran sosial yang tinggi dan berperilaku benar, berakhlak mulia, bertanggung jawab, multi disiplin, terampil dalam berbagai hal, dan berani.

Kampus sebagai salah satu tempat pendidikan Islam diharapkan bisa melahirkan lulusan yang siap terjun ke masyarakat sebagai: karyawan atau pegawai, akademisi, wirausahawan atau entrepreneur dan atau siap untuk 
menjadi Community Development

(Pengembang Masyarakat).

Ada tiga pilar kekuatan ummat Islam yaitu: masjid, pesantren dan kampus. Tiga unsur kekuatan umat tersebut apabila dipertemukan, niscaya akan menjadi modal utama pembinaan umat maupun pembangunan bangsa dan negara, baik di bidang ekonomi, pendidikan, budaya, dan ssebagainya. ${ }^{2}$

Peran kampus dalam membangun ummat melalui pendidikan Ekonomi Islam adalah dengan turut serta dalam menyiapkan Sumber Daya Manusia (SDM) sebagai agent social of change di bidang Ekonomi Islam.

Pada saat ini, kebutuhan SDM Ekonomi Islam sebanyak 184 ribu orang. Tingginya pertumbuhan industri keuangan syariah hingga rata-rata 30 persen membutuhkan dukungan tenaga sumber daya manusia yang profesional. Pada kurun waktu 20 tahun ke depan diperlukan banyak tenaga kerja Islami profesional. $^{3}$

Untuk mewujudkan pembangunan sumber daya manusia yang berkualitas

\footnotetext{
2 Islam Agamaku, Muhammad Natsir: Pilih Islam atau Atheis, badrislam.blogspot.com, 02 Mei, 2009.

${ }^{3}$ Data dari Prof Dr. Suroso Imam Zadjuli, Guru Besar UNAIR Surabaya.
}

tersebut masih diperlukan tenaga kerja Islami sebanyak 184.800 orang. Jumlah tersebut terdiri dari 8.400 tenaga doktor ilmu ekonomi Islam, 25.200 lulusan magister ekonomi Islam, lulusan sarjana sebanyak 50.400 orang, dan tenaga ahli madya 100.800 orang. ${ }^{4}$

Maraknya kajian-kajian tentang ilmu Ekonomi Islam tidak dapat dipisahkan dari fenomena kebangkitan kembali masyarakat Muslim untuk menghidupkan ajaran-ajaran Islam yang orisinil di berbagai belahan dunia Islam. Kebangkitan Islam yang melanda hampir di seluruh dunia Islam kini tengah mencari suatu tatanan baru yang tidak hanya mencakup aspek ideologis, moral, kultural dan politik saja, tetapi juga aspek ekonomi. Penggerak utama di balik kebangkitan ini ialah keinginan untuk merekonstruksi struktur masyarakat dan perekonomiannya dengan mengadopsi nilai-nilai keimanan, agama, dan tradisi sejarah mereka. ${ }^{5}$

Berbagai program studi perbankan/ekonomi syariah yang kian

\footnotetext{
${ }^{4}$ Data dari Prof Dr. Suroso Imam Zadjuli, Guru Besar UNAIR Surabaya.

5 Euis Amalia, dkk. (2012). Potret Pendidikan Ekonomi Islam di Indonesia. Jakarta: Gramata Publishing. hlm 32.
} 
menjamur di sejumlah sekolah tinggi atau perguruan tinggi nasional, tidak menjamin tersedianya pasokan SDM yang berkualitas terhadap industri perbankan syariah. Hal ini disebabkan antara penawaran dan permintaannya belum klop, belum klik. ${ }^{6}$

Penyebab mismatch SDM perbankan syariah bermula dari ketiadaan kurikulum komprehensif yang bisa menjawab kebutuhan pelaku industri perbankan syariah sekaligus kebutuhan pengembangan ilmu keuangan syariah (akademis). ${ }^{7}$

Seharusnya pihak yang berkepentingan seperti Departemen Pendidikan Tinggi, Bank Indonesia, dan pelaku industri perbankan syariah duduk bareng dan membahas kurikulum bersama-sama untuk standar pendidikan SDM perbankan syariah. ${ }^{8}$

Perguruan tinggi memiliki peran yang sangat strategis dalam upaya pengembangan sumber daya manusia pada masa yang akan datang. Kualitas sumber daya manusia dapat tercapai berkat adanya peningkatan kualitas perguruan tinggi. 2011.

6 Wawancara Republika, Kamis, 25-11-

${ }^{7}$ Wawancara Republika, Kamis, 25-11-2011.

${ }^{8}$ Wawancara Republika, Kamis, 25-11-2011.
Peningkatan kualitas lulusan perguruan tinggi, diperlukan peningkatan sistem pendidikan, yang intinya terletak pada kurikulum yang dikembangkan dan dilaksanakan pada lembaga pendidikan tinggi. Kurikulum dapat dianggap sebagai suatu alat yang penting dalam upaya mencapai tujuan pendidikan tinggi. Tanpa kurikulum yang sesuai dan tepat akan sulit untuk mencapai tujuan dan sasaran pendidikan yang diinginkan.

Standar kurikulum ekonomi Islam di perguruan tinggi tidak lepas dari Tauhid yang merupakan fondasi seorang Muslim dalam melakukan aktifitas kehidupan sehari-hari. Oleh karenanya, seorang Muslim yang dipersiapkan dan dididik di sekolah tinggi ekonomi Islam dalam pendidikannya mesti mempelajari Tauhid tersebut.

Paradigma Tauhid berbicara tentang Aqidah Islamiyah. Sehingga dalam penjelasan yang lebih luas, dikemukakan bahwa Aqidah Islamiyah adalah: Keimanan yang teguh dan bersifat pasti kepada Allah S.W.T. dengan segala pelaksanaan kewajiban bertauhid (Tauhid Rububiyyah, Tauhid Uluhiyah dan Asma' dan Shifat Allah) dan taat kepada-Nya, beriman kepada 
Malaikat-Malaikat-Nya, Rasul-rasulNya, Kitab-kitab-Nya, Hari Akhir, Taqdir baik dan buruk dan mengimani seluruh apa-apa yang sudah shahih tentang prinsip-prinsip Agama (Ushuluddin), perkara-perkara yang ghaib, beriman kepada apa yang menjadi ijma' (konsensus) dari Salafus Shalih, serta seluruh berita-berita qath' $i$ (pasti), baik secara ilmiah maupun secara amaliyah yang telah ditetapkan menurut al-Quran dan as-Sunnah yang shahih serta ijma' Salafus Shalih ${ }^{9}$

Mengacu pada penjelasan tersebut, maka tatkala seorang Muslim melakukan aktivitas kehidupannya termasuk di dalamnya adalah aktivitas studi Ekonomi Islam, sesungguhnya dia juga sedang berada dalam aktivitas untuk mempersiapkan bekal bagi kehidupan sesudah mati, tanpa melupakan kewajiban-kewajibannya, baik terhadap dirinya, terhadap sesama manusia dan terhadap alam lingkungannya sebagai khalifah Allah S.W.T. di muka bumi.

Seorang Muslim yang belajar ekonomi Islam akan senantiasa mempertimbangkan akibatnya pada hari

9 Yazid bin Abdul Qadir Jawas. (2004). Syarah Aqidah Ahlus Sunah wal Jama'ah. Bogor: Pustaka At-Taqwa. hlm. 2. kemudian, artinya menurut dalil ekonomi, orang akan membandingkan manfaat dan biaya (benefit-cost) dalam memilih kegiatan ekonomi dengan menghitung nilai sekarang dari hasil yang akan dicapai pada masa mendatang. Hasil kegiatan mendatang ini adalah semua yang diperoleh baik sebelum maupun sesudah mati. ${ }^{10}$

Perguruan tinggi di Indonesia memiliki potensi yang besar dalam menyiapkan SDM integratif yaitu memiliki kompetensi yang memadai dari aspek syariah sekaligus mumpuni dalam bidang ekonomi dan keuangan baik dari segi konsep maupun operasional. Hanya saja saat ini di berbagai perguruan tinggi agama/perguruan tinggi agama Islam swasta dan perguruan tinggi umum ditemui fakta masih terjadinya keragaman struktur akademik yaitu posisi bidang Kajian Ekonomi Islam dalam bentuk program studi, konsentrasi maupun baru sebatas mata kuliah pilihan. Implikasinya kurikulum belum terintegrasi sehingga pemahaman tentang ekonomi Islam masih bersifat

10 Ahmad M. Saefuddin. (1404/1984). Studi Nilai-Nilai Sistem Ekonomi Islam. Jakarta: Media Dakwah. 
parsial dan kekaburan pada kompetensi utama yang akan dihasilkan.

Metode belajar mengajar yang harus ditawarkan adalah pengembangan sistem pendidikan ekonomi Islam integratif, muatan kurikulum perlu menggambarkan sasaran-sasaran yang hendak dicapai. Ini meliputi:

1. Penguasaan bahasa Arab dan bahasa Inggris,

2. Pengusaan ilmu-ilmu dasar kesyariahan seperti tauhid, qawaid fiqhiyyah, ushul fiqh, dan fiqh muamalat,

3. Penguasaan ilmu ekonomi Islam,

4. Penguasaan ilmu ekonomi umum termasuk aspek keuangan dan akuntansi, dan

5. Penguasaan metodologi penelitian, baik penelitian kualitatif maupun penelitian kuantitatif. ${ }^{11}$

Munculnya program studi Ekonomi Islam di berbagai perguruan tinggi menunjukkan dinamika keilmuan dan antusiasme masyarakat terhadap kajian ini. Oleh karena itu, perlu standarisasi kurikulum dan metode belajar mengajar demi tercapainya kompetensi lulusan yang diharapkan dengan tetap

\footnotetext{
${ }^{11}$ Euis Amalia, dkk. (2012). hlm. 35
}

memberikan ruang bagi masing-masing universitas untuk mengembangkan kurikulum dan metode belajar mengajarnya.

Partisipasi kalangan pelaku industri dalam memberikan masukan kurikulum dan metode belajar mengajar ekonomi Islam di perguruan tinggi juga perlu diintensifkan dan lebih jauh lagi diharapkan mejadi kolaborasipartisipasi antara dunia industri dan perguruan tinggi dalam menciptakan SDM profesional yang dibutuhkan.

Fondasi Tauhid dalam pendidikan Ekonomi Islam adalah dengan menanamkan Aqidah Islamiyah yang benar dan integratif.

Mahasiswa ekonomi Islam, tidak sekedar mengandalkan aspek profesionalisme dalam arti sisi peradabannya saja (infra struktur, yang sifatnya furu'iyah), akan tetapi kokoh dalam tsaqafahnya (yang sifatnya ushul : aqidahnya, fikrahnya, tradisi dan kultur Islamnya).

Kesalahan fatal yang terjadi sekarang di dunia pegiat ekonomi syariah, terbukti dengan banyaknya perbankan syariah dan Bank Perkreditan Rakyat Syariah (BPRS) dadakan, yang hanya bermodalkan training dan 
rekrutmen, lebih pada aspek-aspek teknis keprofesian, dan bukan pada pembinaan fondasinya, yaitu amal-amal hati yang menggerakkan seluruh amalamal anggota badannya, apalagi di bank-bank konvensional yang membuka layanan Bank Syariah. Yang hanya memanfaatkan trend umat Islam yang mayoritas ini. Mereka keropos fondasi tauhidnya, tsaqafah Islamiyahnya, fikrah, dan pemahaman ubudiyahnya, adab dan akhlaknya.

Kewajiban amal hati merupakan asas dari amal anggota badan, sementara amal anggota badan sebagai tanda dan bukti adanya amalan hati. Bagi praktisi ekonomi syariah yang namanya pembukuan, akunting, auditing, dan transparansi hanyalah merupakan sisi peradaban sebagai bukti fisik administrasi. Sementara praktik ribawi, spekulasi, menzhalimi orang, memakan harta orang lain dengan cara zhalim, tipu menipu dan sejenisnya justru sebagai prinsip yang asasnya adalah amal hati. Orang yang tidak beriman, hakikatnya tidak boleh diberi kepercayaan, apalagi dalam soal mu`amalah harta. Oleh karena itu mengapa ketika seorang Muslim bekerja sama (mudlarabah atau musyarakah) dengan orang kafir (tak beriman), dibolehkan dengan syarat: pelaku (yang menjalankan bisnisnya) haruslah yang Muslim (yang mengerti fiqh mu`alamah, haram dan halal, hak dan batil, riba dan qardl, zhalim dan adil, memahami jenis-jenis akad dalam mu`amalah harta, membedakan satu akad dengan yang akad lainnya), sedang pemodalnya dari yang kafir. Tidak boleh sebaliknya. Itulah mengapa Umar bin Khatthab ra melarang pedagang masuk pasar (melakukan transaksi jual beli) kecuali bagi mereka yang memahami fiqh mu`amalah. Oleh karena itu, setiap Muslim yang akan berbisnis di lembaga keuangan syariah terlebih dahulu harus mempelajari dan memahami fiqh mu'amalah yang ada di perguruan tinggi. Oleh karenanya, pengembangan institusi dan kurikulum pendidikan ekonomi dan keuangan syariah menjadi solusi yang paling tepat. $^{12}$ Berdasarkan hal tersebut, maka betapa pentingnya pengembangan kurikulum ekonomi Islam berbasis Tauhid di perguruan tinggi yang ada di

12 Irfan Syauqi Beik. (2012). Model Kurikulum Pendidikan Ekonomi Islam di Perguruan Tinggi Umum dan Asia Tenggara. Jurnal Ekonomi Islam Al-Infaq, 03(01). hlm. 15-24. 
Indonesia dalam menyiapkan sumber daya manusia yang akan terjun dalam lembaga keuangan syariah kelak.

\section{B. METODE PENELITIAN}

Jenis penelitian ini menggunakan metode penelitian studi kasus. Data diperoleh dari wawancara, pengamatan, dan studi dokumen. Adapun jenis penelitiannya adalah penelitian kualitatif deskriptif analitis yang berupaya menuangkan data yang diperoleh dalam bentuk deskripsi (gambaran naratif) bukan dalam bentuk angka-angka. Penelitian kualitatif bertujuan untuk menggali makna terdalam dari perspektif subjek atau partisipan yang diteliti. Langkahlangkah atau prosedur yang dilaksanakan adalah:

Teknik pengumpulan data dilakukan dengan cara wawancara dengan Pakar Ekonomi Islam, Dosen Ekonomi Islam, Ketua Matrikulasi, staf, mahasiswa, pengguna alumni, dan alumni Ekonomi Islam.

Analisa data yang digunakan dalam penelitian ini menggunakan jenis penelitian kualitatif dengan metode penelitian dan pengembangan ( $R \& D)$.

\section{B. PEMBAHASAN KURIKULUM EKONOMI ISLAM}

Kurikulum berasal dari kata "curriculae" yang berarti lintasan yang harus ditempuh seorang pelari. Secara etimologi, kurikulum berasal dari bahasa Yunani, yaitu curir yang berarti berlari dan curere yang artinya tempat berpacu. $^{13}$ Dalam bahasa Latin "curriculum" semula berarti a running course, or race course, especially a chariot race course dan terdapat pula dalam bahasa Prancis "courier" artinya "to run, berlari". Kemudian istilah itu digunakan untuk sejumlah "courses" atau mata pelajaran yang harus ditempuh untuk mencapai suatu gelar atau ijasah. ${ }^{14}$

Kurikulum adalah seperangkat rencana dan pengaturan mengenai isi dan bahan pelajaran serta cara yang digunakan sebagai pedoman penyelenggaraan kegiatan belajar mengajar di suatu lembaga pendidikan. ${ }^{15}$

Kurikulum merupakan komponen penting yang terdiri dari rencana

13 Abdullah Idi. (2007). Pengembangan Kurikulum Teori dan Praktik. Yogyakarta: ArRuzz Media. hlm. 183.

14 S. Nasution. (2003). Pengembangan Kurikulum. Bandung: PT Citra Aditya Bakti. hlm. 9.

15 M. Zainuddin. (2009). Pendidikan Islam dari Paradigma Klasik Hingga Kontemporer. Malang: UIN Malang Press. hlm. 168. 
program pendidikan yang akan diberikan kepada mahasiswa. Pengembangan kurikulum adalah proses yang tak henti-hentinya, yang harus dilakukan secara kontinyu. Jika tidak, maka kurikulum akan mejadi usang atau ketinggalan zaman. Makin cepat perubahan dalam masyarakat, makin sering diperlukan penyesuaian kurikulum. $^{16}$

Kelemahan kurikulum Perguruan Tinggi Agama Islam (PTAI) saat ini adalah strukturnya yang tidak jelas. Kurikulum saat ini hanya berupa deretan nama mata kuliah dengan tujuan kurikuler yang terlalu umum. Setiap orang akan dapat menafsirkan maksud kurikulum itu berdasarkan pandangan masing-masing. Dalam proses pendidikan, di mana semua orang (pimpinan, dosen, karyawan, pustakawan, laboran, dan sebagainya) harus bekerja sama dalam satu tim, perbedaan persepsi mengenai rencana program pendidikan ini akan sangat menyulitkan pencapaian tujuan pendidikan tersebut. ${ }^{17}$

16 S. Nasution. (1995). Asas-Asas Kurikulum. Bandung: Jemmars. hlm. 3.

17 Samsul Nizar dan Muhammad Syaifudin. (2010). Isu-isu Kontemporer tentang Pendidikan Islam. hlm. 271.
Pada hakikatnya suatu kurikulum adalah suatu rencana itu sendiri. Jika kita mengajukan konsep perencanaan kurikulum, itu berarti kita berbicara tentang cara merencanakan suatu rencana tersebut. Perencanaan kurikulum berarti merencanakan kesempatan-kesempatan belajar bagi peserta didik supaya terjadi perubahan perilaku yang diinginkan. Ini berarti, perubahan perilaku adalah tujuan atau hasil yang diharapkan. Kesempatan belajar mengandung isi atau materi yang perlu dipelajari dan cara mempelajarinya. ${ }^{18}$

Strategi pengembangan kurikulum perguruan tinggi dilakukan melalui tahap-tahap sebagai berikut:

1. Studi Kelayakan dan kebutuhan

2. Penyusunan konsep awal perencanaan kurikulum

3. Penyusunan rencana untuk pelaksanaan kurikulum

4. Pelaksanaan uji coba kurikulum di lapangan

5. Pelaksanaan kurikulum

6. Pelaksanaan penilaian dan pemantauan kurikulum

7. Pelaksanaan perbaikan/ penyempurnaan dan penyesuaian

${ }^{18}$ Oemar Hamalik. (1994). hlm. 41. 
Dengan system dan prosedur ini, pengembang kurikulum pada gilirannya akan memperoleh kurikulum baku. ${ }^{19}$

Ekonomi Islam merupakan suatu ilmu yang multidimensi/interdisipliner, komprehensif, dan saling terintegrasi, meliputi ilmu syariah yang bersumber dari Al-Quran dan As-Sunnah, dan juga ilmu rasional (hasil pemikiran dan pengalaman), dimana dengan ilmu ini manusia dapat menyelesaikan masalah yang dihadapi untuk kemaslahatan dan falah. $^{20}$

Kata al-falah mengandung makna kesejahteran dunia dan akhirat sebagaimana makna doa "sapu jagat", rabbana atina fi dunya hasanah wa fi al-akhirati hasanah waqina azaba alnar.

Pengertian al-falah dalam pengertian konsep kesejahteraan di dunia mengandung tiga makna utama:
(1) al-baqa'(survive),
(2) al-gana

(freedom from want), dan (3) al-'izz (power and honour). ${ }^{21}$

Adapun makna konsepsional kesejahteraan di akhirat mengandung

\footnotetext{
${ }^{19}$ Oemar Hamalik. (1994). hlm. 55.

${ }^{20}$ Mustafa Edwin Nasution, Ketua Umum Ikatan Ahli Ekonomi Islam (IAEI) yang pertama.

${ }^{21}$ Q.S. Al-Baqarah (2): 201.
}

makna: (1) baqa bila fana (eternal survival), (2) gana bila faqr (eternal prosperity), (3) izz bila dull (everlasting glory), dan (4) 'ilm bila jahl (knowledge from ignore). ${ }^{22}$

Kondisi atau syarat-syarat kesejahteraan yang harus dicapai dalam ilmu ekonomi Islam meliputi: (1) kesejahteraan spiritual, kesejahteraan ekonomi, kesejahteraan cultural, dan

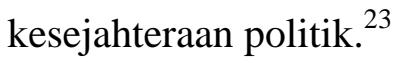

Sistem ekonomi Islam berpatokan pada empat dasar hipotesa: (1) aktifitas ekonomi yang berkaitan dengan persatuan, (2) keseimbangan antara produksi, konsumsi dan distribusi, (3) kebebasan individu dan negara sebagai refleksi dari kebebasan manusia dalam konsep Islam, dan (4) bertanggung jawab pada redistribusi dan sumber daya di antara kelas dan kelompok yang ada di masyarakat. ${ }^{24}$

Prinsip Dasar Ekonomi Islam terdiri dari: (1) Tauhid, (2) Maslahah dan Falah, (3) Khalifah (Wakil Allah di

22 Juhaya S. Pradja. (2012). Ekonomi Syariah. Bandung: Penerbit CV Pustaka Setia. hlm. 57.

${ }^{23}$ Juhaya S. Pradja. (2012). hlm. 57.

24 Syed Nawab Haider Naqvi. (1981). Ethict and Economics An Islamic Sinthesis. U.K.: The Islamic Foundation. hlm. 62. 
muka bumi), (4) Al-Amwal (Harta), (5)
$A d l$
(Adil),
(6)
Ukhuwah

(Persaudaraan), (7) Akhlak (Etika), (8) Ulil Amri (Pemerintah), (9) Hurriyah dan Mas'uliyah (Kebebasan dan Tanggung jawab), dan (10) Berjamaah (Kerjasama Sinergi) $^{25}$

Kurikulum ekonomi Islam penting dikembangkan agar muncul lulusan yang kaffah keislaman dan keilmuan, pionir dan subyek perubahan, terserap di pasar, pemain regional, nasional, global baik mikro maupun makro, serta menjadi pusat pengembangan dan rujukan dalam teori, kelembagaan, keahlian, produk, dll.

Tauhid adalah landasan bagi penumbuhkembangan karakter insan Muslim dalam segala sendi kehidupan, termasuk di dalamnya pengelolaan sumber daya insani melalui pendidikan ekonomi Islam. Hal ini sangat mendasar karena sebuah konsep tanpa landasan yang kokoh maka dia akan menjadi sesuatu yang rapuh "termakan" atau terpengaruh oleh variabel-variabel lainnya. Hakikat Tauhid dalam hal ini adalah berbicara tentang Aqidah Islamiyah. Definisi Aqidah mengacu

${ }^{25}$ Rikza Maulan. Training Ekonomi Islam, Sekretaris DPS Takaful. Takaful Indonesia. pada Lisaanul 'Arab karya Ibnu Manzhur dan Mu'jamul Wasiith Aqidah menurut bahasa berasal dari kata "al'Aqdu yang berarti ikatan, at-Tautsiqu yang berarti kepercayaan atau keyakinan yang kuat, al-Ihkamu artinya mengokohkan/menetapkan, dan arrabthu bi quwwah yang berarti mengikat dengan kuat. Sedangkan menurut istilah adalah iman yang teguh dan pasti, yang tidak ada keraguan sedikitpun bagi orang yang meyakininya. ${ }^{26}$

Sehingga dalam penjelasan yang lebih luas, dikemukakan bahwa Aqidah Islamiyah adalah Keimanan yang teguh dan bersifat pasti kepada Allah S.W.T dengan segala pelaksanaan kewajiban bertauhid (Tauhid Rububiyyah, Tauhid Uluhiyah dan Asma' dan Shifat Allah) dan taat kepada-Nya, beriman kepada Malaikat-Malaikat-Nya, Rasul-rasulNya, Kitab-kitab-Nya, Hari Akhir, taqdir baik dan buruk dan mengimani seluruh apa-apa yang sudah shahih tentang Prinsip-prinsip Agama (Ushuluddin), perkara-perkara yang ghaib, beriman kepada apa yang menjadi ijma' (konsensus) dari

26 Yazid bin Abdul Qadir Jawas. (2004). hlm. 1. 
Salafushalih, serta seluruh berita-berita qath'i (pasti), baik secara ilmiah maupun secara amaliyah yang telah ditetapkan menurut Al-Quran dan AsSunnah yang shahih serta ijma' Salafushalih $^{27}$

Pengertian Islam telah
dikemukakan oleh Abul A'la Maududi, beliau memberikan pengertian secara ringkas terhadap arti kata Islam yakni "taat kepada Allah dan tunduk kepada perintah-Nya tanpa membantah. ${ }^{28}$ Dalam konteks tafsir, Quraish Shihab memberikan penjelasan bahwa nama Islam mengandung arti dan makna "ajaran yang mendambakan perdamaian". 29

Aqidah yang benar adalah perkara yang amat penting dan kewajiban yang paling besar yang harus diketahui oleh setiap Muslim dan Muslimah. Karena sesungguhnya sempurna atau tidaknya suatu amal, diterima atau tidaknya amal bergantung kepada aqidah yang benar. Kebahagiaan dunia dan akhirat dapat diperoleh oleh orang-orang yang

27 Yazid bin Abdul Qadir Jawas. (2004). hlm. 2.

28 Abul A’la Maududi. (1986). PrinsipPrinsip Islam. Jakarta: International Islamic Federation of Student Organizations. hlm. 2.

${ }^{29}$ M. Quraish Shihab. (1999). Wawasan AlQuran. Jakarta: Penerbit Mizan. hlm. 378. berpegang pada aqidah yang benar ini dan menjauhkan diri dari hal-hal yang menafikan dan mengurangi kesempurnaan aqidah tersebut. ${ }^{30}$

Fondasi Tauhid bagi seorang mahasiswa Muslim menjadi sesuatu yang sangat fundamental karena beberapa pertimbangan antara lain: ${ }^{31}$

a. Aqidah yang benar adalah fundamen bangunan Islam yang harus ditegakkan pada setiap pribadi mahasiswa Muslim.

b. Memurnikan Tauhid adalah tugas setiap Muslim dalam kehidupannya. Seorang Muslim memulai kehidupannya dengan Tauhid. Mengakhiri hidup ini dengan Tauhid.

c. Seluruh aspek kehidupan seorang Muslim harus didasari dengan Tauhid termasuk dalam menuntut ilmu, hidup bermasyarakat atau bekerja, beliau bersabda: "Demi Allah yang diriku ada di tangan-Nya tidak beriman seseorang hamba hingga ia mencintai tetangganya sebagaimana mencintai dirinya" (Muttafaqun 'alaih).

30 Yazid bin Abdul Qadir Jawas. (2004). hlm. xiii.

${ }^{31}$ Hayat Setiawan. (2005). Urgensi Aqidah dalam Membentuk Pribadi Muslim. Makalah Pengajian. Jakarta: Yayasan Al-Wafa. 
d. Hakikat ajaran Islam didirikan di atas Tauhid, Allah S.W.T. tidak menerima seseorang yang menyekutukan-Nya, sebagaimana firman-Nya:

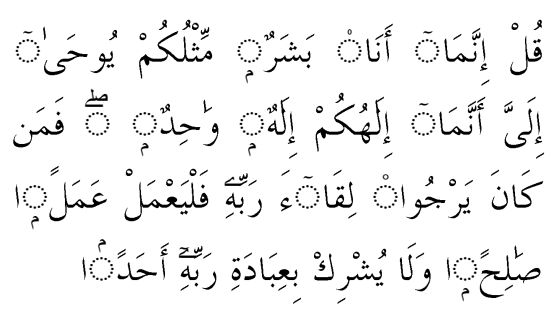

Katakanlah: "Sesungguhnya aku ini hanya seorang manusia seperti kamu, yang diwahyukan kepadaku: "Bahwa sesungguhnya Rabb kamu itu adalah Tuhan Yang Esa”. Barang siapa mengharap perjumpaan dengan Tuhannya, maka hendaklah ia mengerjakan amal yang saleh dan janganlah ia mempersekutukan seorangpun dalam beribadat kepada Tuhannya". (Q.S. Al-Kahfi [18]: 110).

e. Tauhid menjamin seseorang masuk surga, sabda Rasulullah Shalallohu 'alaihi wa Sallam:

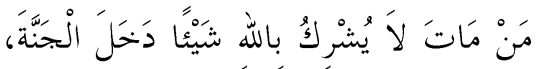

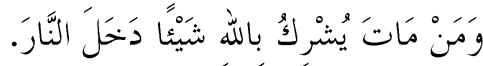

Barangsiapa meninggal dalam keadaan tidak berbuat syirik kepada Allah sedikitpun, niscaya akan masuk surga. Dan barangsiapa meninggal dunia (dalam keadaan) berbuat syirik kepada Allah niscaya akan masuk neraka. (H.R. Muslim).

\section{HASIL PEMBAHASAN KURIKULUM EKONOMI ISLAM}

Tujuan kurikulum yang ada di Prodi Ekonomi Islam STEI Tazkia:

1. Berlandaskan Syariah, filsafat ilmu serta metode pengembangan Program Studi Ekonomi Islam.

2. Menjadi referensi kurikulum nasional dalam pengembangan Program Studi Ekonomi Islam.

3. Mempunyai kompetensi serta indikator kuantitatif maupun kualitatif lulusan Prodi Ekonomi Islam yang dapat memenuhi kebutuhan lembaga bisnis Islam baik di sektor riil maupun sektor keuangan.

4. Terjalinnya kerjasama dan kemitraan institusional yang saling menguntungkan dengan lembaga pendidikan tinggi lain dan industri baik di dalam maupun di luar negeri. $^{32}$

\footnotetext{
${ }^{32}$ Student Guide STEI Tazkia.
} 
Untuk mewujudkan tujuan tersebut, pendidikan diselenggarakan dalam satu kesatuan dan tahapan yang jelas yaitu: (1) Seleksi TPA/Smart Test/Seleksi Berkas, (2) Program Matrikulasi (Semester 1 - Semester 2), (3) Perkuliahan (UTS, UAS, Magang, Skripsi, Ujian Komprehensif, (4) Boarding tugas akhir, dan (5) Bursa Alumni. $^{33}$

Berdasarkan hasil kuesioner yang diedarkan kepada pengguna, mahasiswa, alumni dan dosen menyatakan bahwa perencanaan kurikulum ekonomi Islam sudah baik sebanyak 35 orang, menyatakan belum baik sebanyak 1 orang. ${ }^{34}$

Selanjutnya berdasarkan hasil kuesioner yang diedarkan kepada pengguna, mahasiswa, alumni dan dosen menyatakan bahwa pelaksanaan kurikulum ekonomi Islam sudah baik sebanyak 29 orang, menyatakan belum baik sebanyak 7 orang. ${ }^{35}$

Temuan evaluasi kurikulum yang ada di Prodi Ekonomi Islam dilakukan evaluasi kurikulum setiap 4 tahun sekali dengan membandingkan Berita Acara Perkuliahan dengan Satuan Acara
Perkuliahan, mencatat masukan dosen dan mahasiswa (dari Instruksi Kerja/IK keluhan Pelanggan), pengguna dan Alumni (dari Prosedur Kerja/PK Telusur Alumni), serta temuan audit internal dan eksternal penjaminan mutu. Selanjutnya diteruskan dengan membentuk Tim untuk membahas masukan tentang kurikulum; Melakukan pembahasan dengan notulensi yang akan dibawa ke rapat (Workshop Akademik). ${ }^{36}$

Ruang lingkup pengembangan kurikulum di program studi ekonomi Islam meliputi Evaluasi, Perbaikan, dan Penyusunan Kurikulum serta mengadakan workshop akademik. Kemudian diadakan Perbaikan dan Pembuatan Modul, Satuan Acara Perkuliahan (SAP) dan Silabus. ${ }^{37}$

$$
\text { Sedangkan langkah-langkah }
$$
pengembangan kurikulum meliputi (1). Pengembangan tujuan pendidikan. (2). Pengembangan kurikulum Kementrian Pendidikan Tinggi, kurikulum Kemenag, kurikulum sekolah tinggi ekonomi Islam, dan kurikulum dari lembaga pendidikan luar negeri kemudian disesuaikan dengan visi dan

\footnotetext{
33 Student Guide STEI Tazkia.

${ }^{34}$ Hasil kuesioner.

${ }^{35}$ Hasil kuesioner.
}

\footnotetext{
${ }^{36}$ SOP STEI Tazkia.

${ }^{37}$ SOP STEI Tazkia.
} 
misi STEI Tazkia yang meliputi kurikulum matrikulasi, ekonomi Islam, dan bahasa (3). Pengembangan bentuk pengelolaan belajar (4). Pengembangan metode pembelajaran

Pengembangan program pengembangan diri (life skill) (6). Pengembangan kegiatan out door learning, dan (7). Pengembangan evaluasi pembelajaran.

Berdasarkan hasil kuesioner yang diedarkan kepada pengguna, mahasiswa, alumni dan dosen menyatakan bahwa kurikulum perlu dikembangkan sebanyak 28 orang, tak perlu dikembangkan sebanyak 8 orang. 38

Sedangkan responden yang menyatakan perlu pengembangan kurikulum ekonomi Islam yang bermuatan nilai-nilai Tauhid sebanyak 26 orang, yang tak perlu pengembangan dengan nilai Tauhid sebanyak 10 orang. 39

Adapun kurikulum yang perlu dikembangkan menurut responden adalah untuk mata kuliah: Filsafat Ekonomi Islam, Akuntanis Syariah, Manajemen Sumber Daya Manusia, Fiqh Muamalah, Makroekonomi Islam,

\footnotetext{
${ }^{38}$ Hasil kuesioner.

${ }^{39}$ Hasil kuesioner.
}

Manajemen, Tauhid/Aqidah, Mata kuliah yang lebih aplikatif, Quantitative Method, Mikro Syariah, Makro Syariah, Marketing, Ekonomi Islam, Manajemen Keuangan, Pemikiran Ekonomi Islam, Kewirausahaan, Semua Mata Kuliah, Bisnis Berbasis Akidah, dan Etika Bisnis. $^{40}$

Responden yang menyatakan puas terhadap pelaksanaan kurikulum Ekonomi Islam sebanyak 32 orang, tidak puas sebanyak 4 orang. Mereka menyatakan puas karena sudah memenuhi kebutuhan, sudah tersusun dengan baik, lulusannya bisa bersaing di dunia kerja, banyak alumni yang terserap. Mereka yang menyatakan kurang puas karena sarana prasarana masih kurang dan kurang praktik di lapangan. ${ }^{41}$

Kurikulum Prodi Ekonomi Islam STEI Tazkia dirancang berdasarkan kebutuhan dunia usaha dan bisnis terutama yang berbasis Islam serta mengikuti perkembangan terkini dalam khazanah ilmu pengetahuan di bidang Ilmu ekonomi Islam. Kurikulum ini diharapkan dapat menghasilkan lulusan yang dapat menjalankan fungsinya

\footnotetext{
${ }^{40}$ Hasil kuesioner.

${ }^{41}$ Hasil kuesioner.
} 
sebagai profesional, akademisi, entrepreneur, community development yang siap pakai.

Mahasiswa harus menyelesaikan sekurang-kurangnya 155 (seratus lima puluh lima) SKS untuk program studi Ekonomi Islam. Masa studi ditempuh dalam waktu minimal 8 (delapan) semester dan maksimal 14 (empat belas) semester. Jumlah SKS ini tidak termasuk program bahasa dan program pembinaan. $^{42}$

Pelaksanaan

pengembangan kurikulum sesuai pembahasan sebelumnya adalah merupakan proses siklus, yang tidak pernah berakhir. Proses tersebut terdiri dari empat unsur, yakni: 1. Tujuan, 2. Metode dan Material, 3. Penilaian (assesment), dan 4. Balikan (feedback).

Bentuk konseptual pengembangan kurikulum yang diusulkan dengan mengintegrasikan kurikulum Tauhid ke setiap mata kuliah dengan memasukkan nilai-nilai: Tauhid/Akidah Islamiyah, AlIman, Makrifatullah, Makrifatul Rosul, Makrifatul Islam, Akhlakul Karimah/Ukhuwah Islamiyah.

Melalui materi Tauhid diharapkan

\footnotetext{
${ }^{42}$ Buku Panduan Akademik Tazkia. hlm.
} 70 . mahasiswa memahami makna Akidah secara bahasa dan istilah, peserta memahami hubungan Iman kepada Allah dan Akidah Islam, peserta memahami standar nilai Akidah Islam, mahasiswa memahami makna dan jenis Tauhid (Tauhid Uluhiyah, Tauhid Rububiyah, dan Tauhid Asma' wa Sifaat) serta hubungannya dalam konteks kehidupan dan kekaryaan.

Pelaksanaan kurikulum sesuai dengan penjelasan sebelumnya bahwa kurikulum tidak hanya berupa mata kuliah, tapi tidak lepas juga dari tradisi yang ada di Program Studi STEI Tazkia dalam mendapai tujuan kurikulum tersebut. Tradisi adalah perilaku sivitas akademika dalam melakukan perannya masing-masing yang didasari oleh kesadaran yang tinggi atas peran yang disandang dalam meraih cita-cita bersama. ${ }^{43}$ Termasuk di dalamya untuk mencapai tujuan kurikulum yang telah ditetapkan tidak lepas dari tradisi. Tradisi tersebut diantaranya: 1) Penampilan Fisik, 2) Kelembagaan, 3) Profil Dosen, 4) Profil Pegawai, 5) Profil Mahasiswa, 6) Profil Lulusan yang Diharapkan, 7) Sentra Kegiatan

43 Tradisi UIN Malang. 
yang Dikembangkan, 8) Fungsi Masjid, 9) Fungsi Ma'had/Pusat Matrikulasi, 10) Pengembangan Dosen, 11) Pengembangan Perpustakaan, 12) Kemampuan Akademik Dosen yang Diidealkan, 13) Hubungan di dalam Kampus, 14) Hubungan Sivitas Akademika dengan Lembaga, dan 15) Program Studi.

Pengembangan

kurikulum merupakan proses perbaikan, peningkatan, penyesuaian, pembaharuan tujuan, isi, dan bahan pembelajaran sesuai dengan konteks zaman dan kebutuhan peserta didik. Agar pengembangan kurikulum dapat terarah sesuai dengan rencana sekolah, maka perlu diatur dengan baik.

Sesuai pembahasan sebelumnya, pengembangan kurikulum adalah proses yang tak henti-hentinya, yang harus dilakukan secara kontinyu. Jika tidak, maka kurikulum akan mejadi usang atau ketinggalan zaman. Makin cepat perubahan dalam masyarakat, makin sering diperlukan penyesuaian kurikulum. $^{44}$

Kurikulum STEI Tazkia dikembangkan dengan acuan capaian pembelajaran pada kemampuan yang

${ }^{44}$ S. Nasution. (1995). hlm. 3. diperoleh melalui internalisasi pengetahuan, sikap, ketrampilan, kompetensi, dan akumulasi pengalaman kerja. Capaian pembelajaran mahasiswa ditunjukan dengan ijazah yang dikelurkan oleh STEI Tazkia. Di samping itu mahasiswa juga dibekali dengan keterampilan yang diperoleh melalui pendidikan dan pelatihan kerja. Hasil capaian pembelajaran ditunjukkan dengan sertifikat kompetensi.

STEI Tazkia mengembangkan kurikulum berbasis KKNI yang diperkaya dengan nilai-nilai Islam yang terinternalisasi melalui pembudayaan Nilai T-A-Z-K-I-A, yaitu Tauhid, Amanah, Zero Deffect \& Quality, Knowlwedge \& Competence, Innovative \& Istiqomah, dan Achivement Through Team Work. Nilai-nilai di atas dibudayakan melalui beberapa kegiatan seperti:

a. Dzikir Asmaul Husna pekanan yang dilakukan secara rutin pada apel pagi setiap hari Senin jam $08.00-09.00$.

b. 4T (Tahsin, Tahfidz, Tarjim, dan Tafsir) Circle. Program harian sebelum proses belajar mengajar dimulai. Dosen bersama-sama dengan mahasiswa membaca 5 
ayat di dalam Al-Quran yang

dibaca secara berulang dan bersama-sama.

c. Program pekanan student dynamic system (SDS),

Kelompok diskusi Al-Quran dan Siroh Nabawi. ${ }^{45}$

Pengembangan kurikulum sebagai berikut:

\begin{tabular}{|c|c|c|}
\hline No & Kurikulum & $\begin{array}{c}\text { Pengembangan } \\
\text { Kurikulum }\end{array}$ \\
\hline 1. & $\begin{array}{l}\text { Mata Kuliah } \\
\text { Pengembangan } \\
\text { Kepribadian (MPK) }\end{array}$ & $\begin{array}{l}\text { Memasukkan materi } \\
\text { Tauhid dalam } \\
\text { SAP/RPS, silabus dan } \\
\text { bahan ajar }\end{array}$ \\
\hline 2. & $\begin{array}{lr}\text { Mata } & \text { Kuliah } \\
\text { Keilmuan dan } \\
\text { Keterampilan } \\
(\text { MKK) }\end{array}$ & $\begin{array}{l}\text { Memasukkan materi } \\
\text { Tauhid dalam } \\
\text { SAP/RPS, silabus dan } \\
\text { bahan ajar }\end{array}$ \\
\hline 3. & $\begin{array}{lr}\text { Mata } & \text { Kuliah } \\
\text { Keahlian } & \text { Berkarya } \\
(\text { MKB }) & \end{array}$ & $\begin{array}{l}\text { Memasukkan materi } \\
\text { Tauhid dalam } \\
\text { SAP/RPS, silabus dan } \\
\text { bahan ajar }\end{array}$ \\
\hline 4. & $\begin{array}{lr}\text { Mata } & \text { Kuliah } \\
\text { Perilaku } & \text { Berkarya } \\
\text { (MPB) } & \end{array}$ & $\begin{array}{l}\text { Memasukkan materi } \\
\text { Tauhid dalam } \\
\text { SAP/RPS, silabus dan } \\
\text { bahan ajar }\end{array}$ \\
\hline 5. & $\begin{array}{l}\text { Mata Kuliah } \\
\text { Berkehidupan } \\
\text { Bermasyarakat } \\
(\mathrm{MBB})\end{array}$ & $\begin{array}{l}\text { Memasukkan materi } \\
\text { Tauhid dalam } \\
\text { SAP/RPS, silabus dan } \\
\text { bahan ajar }\end{array}$ \\
\hline
\end{tabular}

${ }^{45}$ Renstra STEI Tazkia 2016-2020. hlm. 24.

\section{E. KESIMPULAN}

Perencaan kurikulum pendidikan ekonomi Islam, bertujuan diantaranya untuk:

1) Membentuk mahasiswa yang berkualitas berlandaskan Syariah, filsafat ilmu dan metode pengembangan Program Studi Ekonomi Islam; 2) Menjadi referensi kurikulum nasional dalam pengembangan Program Studi Ekonomi Islam; 3) Mempunyai kompetensi serta indikator kuantitatif maupun kualitatif lulusan Prodi Ekonomi Islam yang dapat memenuhi kebutuhan lembaga bisnis Islam baik di sektor riil maupun sektor keuangan; dan 4) Terjalinnya kerjasama dan kemitraan institusional yang saling menguntungkan dengan lembaga pendidikan tinggi lain dan industri baik di dalam maupun di luar negeri.

Pelaksanaan kurikulum Ekonomi Islam di Program Studi Ekonomi Islam STEI Tazkia Bogor dilakukan secara bertahap dan terus menerus berkelanjutan dengan mengacu kepada visi dan misi lembaga.

Evaluasi kurikulum Ekonomi Islam di Program Studi Ekonomi Islam STEI Tazkia dilakukan secara terus menerus 
berkelanjutan dengan memperhatikan kebutuhan industri, yang selanjutnya pengembangannya terus dilakukan setelah evaluasi setiap 4 tahun sekali dengan memasukkan nilai-nilai Tauhid di setiap mata kuliah.

\section{DAFTAR PUSTAKA}

\section{Sumber dari Jurnal/Penelitian}

Irfan Syauqi Beik. (2012). Model Kurikulum Pendidikan Ekonomi Islam di Perguruan Tinggi Umum dan Asia Tenggara. Jurnal Ekonomi Islam Al-Infaq, 03(01).

\section{Sumber dari Buku}

Amalia, E., dkk. (2012). Potret Pendidikan Ekonomi Islam di Indonesia. Jakarta: Gramata Publishing.

Hamalik, O. (1994). Pengembangan Kurikulum dan Pembelajaran di Perguruan Tinggi. Bandung: PT Trigenda Karya.

Idi, A. (2007). Pengembangan Kurikulum Teori dan Praktik. Yogyakarta: Ar-Ruzz Media.

Jawas, Y.A.Q. (2004). Syarah Aqidah Ahlus Sunah wal Jama'ah. Bogor: Pustaka At-Taqwa.

Maududi, A.A. (1986). Prinsip-Prinsip Islam. Jakarta: International Islamic
Federation of Student Organizations.

Maulan, R. Training Ekonomi Islam, Sekretaris DPS Takaful. Takaful Indonesia.

Naqvi, S.N.H. (1981). Ethict and Economics An Islamic Sinthesis. U.K.: The Islamic Foundation.

Nasution, S. (1995). Asas-Asas Kurikulum. Bandung: Jemmars.

Nasution, S. (2003). Pengembangan Kurikulum. Bandung: PT Citra Aditya Bakti.

Nizar, S. dan Syaifudin, M. (2010). Isuisu Kontemporer tentang Pendidikan Islam.

Pradja, J.S. (2012). Ekonomi Syariah. Bandung: Penerbit CV Pustaka Setia.

Saefuddin, A.M. (1404/1984). Studi Nilai-Nilai Sistem Ekonomi Islam. Jakarta: Media Dakwah.

Shihab, M.Q. (1999). Wawasan AlQuran. Jakarta: Penerbit Mizan.

Setiawan, H. (2005). Urgensi Aqidah dalam Membentuk Pribadi Muslim. Makalah Pengajian. Jakarta: Yayasan Al-Wafa.

Zainuddin, M. (2009). Pendidikan Islam dari Paradigma Klasik Hingga Kontemporer. Malang: UIN Malang Press. 